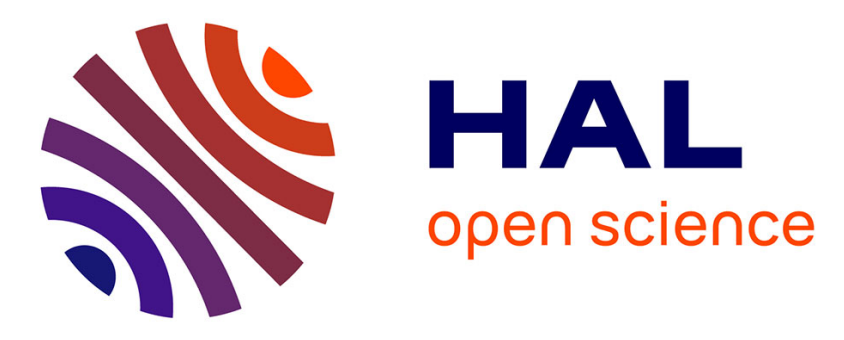

\title{
Understanding the Dilemma of the Municipal Solid Waste Management System in Alexandria, Egypt: Could ICT Improve the System?
}

\author{
Rasha F. Elgazzar, Rania F. El-Gazzar, Mohamed A. El-Gohary
}

\section{To cite this version:}

Rasha F. Elgazzar, Rania F. El-Gazzar, Mohamed A. El-Gohary. Understanding the Dilemma of the Municipal Solid Waste Management System in Alexandria, Egypt: Could ICT Improve the System?. 14th International Conference on Social Implications of Computers in Developing Countries (ICT4D), May 2017, Yogyakarta, Indonesia. pp.816-822, 10.1007/978-3-319-59111-7_67 . hal-01650090

\author{
HAL Id: hal-01650090 \\ https://hal.inria.fr/hal-01650090
}

Submitted on 28 Nov 2017

HAL is a multi-disciplinary open access archive for the deposit and dissemination of scientific research documents, whether they are published or not. The documents may come from teaching and research institutions in France or abroad, or from public or private research centers.
L'archive ouverte pluridisciplinaire HAL, est destinée au dépôt et à la diffusion de documents scientifiques de niveau recherche, publiés ou non, émanant des établissements d'enseignement et de recherche français ou étrangers, des laboratoires publics ou privés. 


\title{
Understanding the Dilemma of the Municipal Solid Waste Management System in Alexandria, Egypt: Could ICT Improve the System?
}

\author{
Rasha F. Elgazzar ${ }^{1}$, Rania F. El-Gazzar², Mohamed A. El-Gohary ${ }^{3}$ \\ ${ }^{1}$ Department of Architectural Engineering and Environmental Design, College of Engineering, \\ Arab Academy for Science, Technology and Maritime Transport, Alexandria, Egypt \\ (arch.rashafahim@gmail.com) \\ ${ }^{2}$ Department of Economics, Marketing and Law, School of Business, University College of \\ Southeast Norway, Hønefoss, Norway \\ (Rania.El-gazzar@usn.no) \\ ${ }^{3}$ Department of Mechanical Engineering, Faculty of Engineering, Alexandria, Egypt \\ (melgohary@alexu.edu.eg)
}

\begin{abstract}
Waste management is one of the significant activities for preserving the environment from pollution that has impact on society mirrored on people's health. This study approaches the topic of waste management using interpretive qualitative case study method to understand problems in the Municipal Solid Waste Management (MSWM) system in Alexandria city, the second largest city in Egypt. Alexandria has been facing a problematic situation with regard to MSWM, which is worth paying attention to. Furthermore, we explore opportunities for benefiting from Information and Communication Technology (ICT) to improve the MSWM system in Alexandria.
\end{abstract}

Keywords. Municipal solid waste management, ICT, environment, sustainable development, developing countries, Alexandria city, waste management problems.

\section{$1 \quad$ Research Problem}

The density of population in developing countries has undesirable implications on many aspects, particularly the environmental sustainable development [1]. One of the key operations to drive the wheel of environmental sustainable development is the $\mathrm{Mu}-$ nicipal Solid Waste Management (MSWM) [2]. MSWM in developing countries is lacking availability of the data in an integrated and timely manner to capture the MSWM system's problems or informal activities and make better decisions [3]. MSWM in developing countries is unsatisfactory [4]; up to $60 \%$ of all the urban solid waste in developing countries is uncollected, less than $50 \%$ of the population is served, and most developing countries use the least preferred waste management methods, such as open dumping and open burning [5]. Developing countries generate organic waste 
far more than the developed countries, which can be turned into 'gold' only if effective waste management programs exist [3].

In Egypt, MSWM has been and will be a constant challenge. The recent estimate of population in Egypt is 91.854.596 according to the Central Agency for Public Mobilization and Statistics (CAPMAS) [6]. Egypt generates 21 million tons of Municipal Solid Waste (MSW) yearly [7], of which $46 \%$ is uncollected and $43 \%$ is covered by formal collection, while $11 \%$ is covered by informal collection [8]. The uncollected MSW is dumped into the river, canals, and streets posing a major threat to the environment (i.e., pollution) and public health (i.e., spread of diseases) [9]. The MSWM system in Egypt is inefficient; one side of this dilemma relates to the improper handling of the MSW and other legal, institutional, financial, and cultural factors. The other side of the dilemma is that there is no adequate data to support the assessment of MSWM sector and inform decision-making regarding the improvement of the MSWM system [10]. The same dilemma applies to Alexandria city, the second largest city in Egypt.

Alexandria city was voted the cleanest city of the Arab world in 2003, a winner of a prize in the environment category in 2005, and awarded the Habitat Scroll of Honour from the United Nations (UN) in 2006. However, several factors (i.e., social, urban, technical, and cultural) and institutional actors (i.e., public, private, and informal sector) contributed to the previously flourished MSWM era and the currently problematic MSW situation. We commenced the study with the following Research Questions (RQs) to understand the MSW problems in Alexandria and the constituents of such problems, and explore opportunities for Information and Communication Technology (ICT) to improve the MSWM system in Alexandria: "RQ1: What are the problems in the MSWM system in Alexandria?" and "RQ2: How can ICT help improving those problems?"

We attempt to define the research problem in relation to the literature and the social context. Literature on MSWM in Egypt mainly focused on exploring techniques for treating organic MSW [11], suggesting a sustainable strategy for MSWM based on successful international models, which is not actualized yet [12], assessing MSWM in Egypt and the role of Public-Private Partnership (PPP) in that process [13], proposing a MSWM quality assurance program that unfortunately lacks in Egypt [14], highlighting the importance of raising the environmental awareness of SWM in the Egyptian education System [15], and proposing standard codes of practice for MSWM in Egypt [16]. However, the power of ICT in improving MSWM system in the Egyptian context has not been explicitly appreciated yet. Very few studies contributed to identifying problems and suggesting solutions for MSWM in three Egyptian governorates, namely, Cairo [17], Port Said [18], and El-Beheira [19]. However, MSWM problems in Alexandria city have not been explored and addressed properly yet given the city is equally important in size and location, and it has been through ups and downs in the process of MSWM that ended in a worse MSW situation.

The approximate population of Alexandria governorate is five million [6], and eight million in the summer due to the massive summer visitors [20]. The MSW generation in Alexandria governorate is 4200 tons per day and 1.53 million tons per year according to a recent report on the state of environment in Egypt 2014 [21]. Alexandria had an experience of unsustainable MSWM system throughout the time. We describe three 
key periods, each period witnessed differences in processes, actors, and issues in the MSWM system in particular and unsustainable MSW situation in Alexandria city in general.

The first period of "manual labor" covers the years before 2000 and witnessed poor MSWM operations that involved manual labor, namely, informal sector (i.e., Zabbaleen who are individual garbage collecting people). It should be noted that the General Authority for Cleanness \& Beautification, that was part of Alexandria governorate, was and is still responsible for the MSWM, but has no active role to mention in Alexandria City. Furthermore, each district had a cleanness unit with its own equipment that still operates until now, but does not have the proper capacity to cover all MSWM responsibilities solely. In addition, waste collection and sweeping activities were not regular causing being scattered by stray animals, which results in a disastrous scene in Alexandria city's streets. Furthermore, waste disposal and treatment activities were unorganized.

The second period of "Veolia/Onyx Company" covers 2001 - 2011 witnessed a flourished era of cleanliness for the city, labor training, and appropriate management of MSW using modern equipment and techniques according to international standards. Veolia is specialized in environmental services including water, waste management, energy, and transportation. Veolia has signed a contract with the governorate of Alexandria in 2000 to commence operations of the waste management system in Alexandria city for the period of 15 years $(2001-2015)$. The contract was the first Public-Private Partnership (PPP) in waste management sector in Egypt, and it included operations of waste collection and transfer, street cleaning, treatment of waste, and rehabilitation of two old dump sites. However, the contract was terminated in 2011 earlier than the agreed termination year in the contract 2015 . Several problems caused early termination of the contract, such as the instability after the Egyptian uprising posed a threat for the company as an investor, delayed financial dues by the governorate for paying wages of the company's labor, and people used to steal garbage cans for storage purposes, which did cost the company buying new garbage cans.

The third period of "Egypt renaissance or Nahdet Misr Company" covers 20112016, the company is established by "Arab Contractors or El-Mokawloon El-Arab Company" that is a public-sector construction and contracting company. Nahdet Misr started officially its waste management duties in December 2011 in collaboration with "Falcon Group Company" specialized in security services, after Veolia's early contract termination in October 2011. Nahdet Misr took over the waste management operations in a critical time at the year of Egyptian uprising in 2011; hence, the company faced major problems. The company did not have enough experience in MSWM, thus, the company hired subcontractor (scavengers) to collect the waste from particular.

\section{Methodological Approach}

In this study, we conducted an interpretive case study method, that is suitable for studying a phenomenon within its social context [22], to investigate the problems that surfaced in the current MSWM system (see Table 1). 
Table 1. Overview on Methodology

\begin{tabular}{ccl}
\hline \multicolumn{2}{c}{ Data collection/analysis } & Description \\
\hline $\begin{array}{c}\text { Primary } \\
\text { data } \\
\text { sources }\end{array}$ & - & $\begin{array}{l}\text { Seven interviews with duration of } 15 \text { minutes to three hours and } 30 \text { minutes with } \\
\text { citizens, labors in Nahdet Misr, Alexandria governate consultants and service direc- } \\
\text { tors }\end{array}$ \\
& $-\quad \begin{array}{l}\text { One of the authors is a consultant for Alexandria governorate projects and has hands } \\
\text { on experience regarding MSWM problems and solutions }\end{array}$ \\
& $-\quad$ Observations by the reserachers in diffrent areas of the Alexandria city \\
& - $\quad$ Recorded videos by the researchers \\
\hline Secondary & Online news articles, posts on online communities (e.g., Facebook), statistical reports by \\
data & CAPMAS, status reports by the Ministry of environment and Egyptian Environmental \\
sources & Affairs Agency, documents published by Veolia Environment Service Company, and re- \\
& ports by other external agencies (i.e., SWEEP-Net) \\
\hline Data analy- & $\begin{array}{l}\text { Data analysis involved applying open coding of the themes that emerged from the data. } \\
\text { sis } \\
\text { Through the framework for MSWM in developing countries [4], we looked in the data at } \\
\text { the political, institutional, social, financial, economic, and technical problems caused by } \\
\text { various actors and led to degrade MSWM processes at present. }\end{array}$ \\
&
\end{tabular}

\section{$3 \quad$ Findings and Discussion}

Our key contributions from this study are: (1) the pressing problems in the current MSWM system at the time of Nahdet Misr company have been identified (See Table 2 ), and (2) the current ICT initiatives have been identified along with their limitations.

Table 2. MSWM problems in Alexandria

\begin{tabular}{|c|c|}
\hline Problems & Description \\
\hline Political & Regulations are neither strict nor clearly defined \\
\hline Institutional & $\begin{array}{l}\text {-Quantity of waste exceeded the agreed quantity in the contract } \\
\text {-Waste management responsibilities are beyond the capacity of the company } \\
\text {-Delayed financial dues by the governorate to the company for paying the wages of its } \\
\text { labor }\end{array}$ \\
\hline Social & $\begin{array}{l}\text {-The workers of Nahdet Misr used to strike for not having their wages paid regularly, } \\
\text { which caused mountains of waste to appear in the streets } \\
\text {-Shortage of labor to be engaged in waste collection and transfer activities } \\
\text {-People do not adhere to MWM-related laws and waste collection times } \\
\text {-People do random burning of waste causing air pollution } \\
\text {-People used to steal garbage bins for storage purposes, which did cost the company } \\
\text { buying new garbage cans } \\
\text {-Random behavior of scavengers causes garbage being scattered in the streets and } \\
\text { makes it difficult for the company to collect the waste } \\
\text {-The increased population density as a result of the illegal high rise residential build- } \\
\text { ings caused an increase in the amount of generated waste than before }\end{array}$ \\
\hline Financial & $\begin{array}{l}\text {-Bearing extra costs of buying new garbage bins instead of the stolen ones } \\
\text {-The company lacked financial resources to buy extra equipment and collaborated with } \\
\text { subcontractors to collect the waste } \\
\text {-The company had financial dues to those subcontractors } \\
\text {-Penalties on the company from the environmental monitoring authority (which is part } \\
\text { of Alexandria governorate) for the delay in lifting the waste and random disposal meth- } \\
\text { ods }\end{array}$ \\
\hline Economic & $\begin{array}{l}\text {-The random behavior of scavengers caused the company not benefiting from the eco- } \\
\text { nomic value of the recyclable waste }\end{array}$ \\
\hline
\end{tabular}




\begin{tabular}{ll}
\hline & -Increased maintenance and labor costs \\
\hline Technical & -The company used rudimentary equipment (i.e., loaders and open top vehicles and tip- \\
& per trucks) and did not have enough waste collection trucks \\
& -The company had few compactor vehicles \\
& -The company had trucks and equipment that needed maintenance \\
& -The company uses open dumps and random open burning, which are the least pre- \\
& ferred methods \\
& -No ICT applications mentioned to organize and track the MSWM system's activities, \\
& only using WhatsApp groups to communicate with waste collectors \\
\hline Environ- & -Problems in the urban infrastructure, such as the narrow streets in the majority of the \\
mental* & city's districts, which are difficult to reach by regular waste collection trucks \\
\hline
\end{tabular}

* Environmental category is not among the strategic issues listed in the MSWM framework [4], but emerged from the findings.

There is a number of scattered initiatives of using ICT in the current MSWM system in Alexandria by different actors. The use of ICT is limited to WhatsApp, Facebook, and Web portal, which had some implications, yet, not actualized impacts on addressing the problems of MSWM in Alexandria: (1) Spreading awareness: this manifested in the effort by Alexandria governorate to use Facebook to launch awareness campaigns through light comics targeting households to separate recyclable waste from the organic waste. (2) Coordinating and monitoring waste collection activities: in Nahdet Misr, the use of WhatsApp is intended to keep communication between the company and the subcontractors and workers who collect the waste from the streets and send them to locations where more labor is needed to collect the waste. In addition, the waste collectors are asked to take photos for the spots they collected the waste from and send the photos via WhatsApp to confirm that they have cleaned up the spot. However, there are still more opportunities for ICT to solve governance problems concerning the phenomenon of scavengers who scavenge the waste after collecting it and before reaching the intermediate stations. (3) Reporting waste-related problems: on the Web portal of Alexandria governorate, there is a section dedicated for the environmental monitoring authority to receive waste related complaints from citizens either through phone numbers or a Web form enabling citizens to upload files/photos about waste-related problems; thus, leveraging citizen involvement.

The use of ICT as is in the current MSWM system in Alexandria is lacking integration of MSWM activities and involved actors. ICT proved to (1) improve route planning and scheduling of waste collection and transportation using GIS applications [23] incorporated with Big Data analytics [24], which can reduce costs of such tedious activities, as they heavily depend on various behavioral patterns of people, (2) automate waste segregation using scanning spectroscopy technology [25], and (3) have the most relevant and direct effect on MSWM through enabling intelligent recycling systems [26]. Advanced ICT solutions (i.e., Big Data, GPS, and GIS database) could improve the current MSWM system in Alexandria and help the Nahdet Misr manage its limited resources efficiently. This study has reported on MSWM problems in Alexandria, and it is part of an ongoing research effort that seeks to propose an integrated solution for some of the identified problems, taking into account social mechanisms of the problems and opportunities for exploiting ICT. 


\section{References}

1. UN: Towards sustainable cities: World Economic and Social Survey 2013. (2013).

2. Bithas, K.P., Christofakis, M.: Environmentally Sustainable Cities. Critical Review and Operational Conditions. Sustain. Dev. 14, 177-189 (2006)

3. UNEP: Municipal Solid Waste: Is it Garbage or Gold?, http://www.unep.org/pdf/UNEP_GEAS_oct_2013.pdf, (2013).

4. Schübeler, P., Wehrle, K., Christen, J.: Conceptual Framework for Municipal Solid Waste Management in Low-Income Countries, (1996).

5. Wilson, D.C., Velis, C.A., Rodic, L.: Integrated Sustainable Waste Management in Developing Countries. In: Proceedings of the Institution of Civil Engineers: Waste and Resource Management. pp. 52-68 (2013).

6. CAPMAS: Statistical Yearbook. (2016)

7. Zaki, T., Khial, A.: Country Report on the Solid Waste Management in Egypt. (2014).

8. Mehlhart, G., Merz, C.: Greenhouse Gas Emissions from MSW Management in Egypt, http://nswmp.net/wp-content/uploads/2016/02/2014-SWM-Forum_GEORG-MEHLHART_ClimateChange_EN-1.pdf, (2014).

9. Al-Akkad, F.: Egypt's Garbage Problem, http://weekly.ahram.org.eg/News/14892/32/Egypt'sgarbage-problem.aspx.

10. Zaki, T., Kafafi, A.G., Mina, M.B., Abd El-Halim, A.E.-H.M., Saber, M.: Annual Report for Solid Waste Management in Egypt. (2013).

11. Elfeki, M., Tkadlec, E.: Treatment of municipal organic solid waste in Egypt. Environ. Sci. 6, 756-764 (2015).

12. Ibrahim, M.I.M., Mohamed, N.A.E.M.: Towards Sustainable Management of Solid Waste in Egypt. Procedia Environ. Sci. 34, 336-347 (2016).

13. Milik, S.M.: Assessment of Solid Waste Management in Egypt During the Last Decade in Light of the Partnership Between the Egyptian Government and the Private Sector2011),).

14. Rahman, R.A., El-Kamash, A.: Planning for a Solid Waste Management Quality Assurance Program in Egypt. Qual. Assur. Journal2007) 59-53 ,11 .).

15. Kandil, S.H., Abou Bakr, H., Mortensen, L.: Incorporating Environmental Awareness of Solid Waste Management within the Education System: (A Case from Egypt). Polym. Technol. Eng. 43, 1795-1803 (2004).

16. Ghosh, S.K., El Sheltawy, S.T., El Sherbiny, S.A., Fouad, M.M.K.: Codes for Solid Waste Management for Developing Countries: India and Egypt. J. Solid Waste Technol. Manag. 42, (2016)

17. World Bank: Project Information Document (Concept Stage) - Cairo Municipal Solid Waste Management Project - P152961,

http://documents.worldbank.org/curated/en/245761468024247659/pdf/PID-Print-P152961-01-052015-1420469398757.pdf, (2014).

18. Badran, M., El-Haggar, S.: Optimization of municipal solid waste management in Port Said-Egypt. Waste Manag. 2006.

19. El-Salam, M.: Municipal Solid Waste Management in El-Beheira Governorate, Egypt: a case study in Damanhour City. J. Environ. Occup. Sci. 2013.

20. Crawford, G.: Public private partnership in the European Union, (2013).

21. EEAA: Egypt State of the Environment Report, http://www.eeaa.gov.eg/enus/mediacenter/reports/soereports.aspx.

22. Walsham, G.: Interpretive Case Studies in IS Research: Nature and Method. Eur. J. Inf. Syst. 4, 74-81 (1995).

23. Rada, E., Ragazzi, M., Fedrizzi, P.: Web-GIS oriented systems viability for municipal solid waste selective collection optimization in developed and transient economies. Waste Manag. (2013).

24. Shahrokni, H., van der Heijde, B., Lazarevic, D., Brandt, N.: Big Data GIS Analytics Towards Efficient Waste Management in Stockholm. In: the 2nd International Conference on ICT for Sustainability (ICT4S 2014) (2014).

25. Durgekar, V.: Towards Sustainable Waste Management Through Technological Innovations, Effective Policy, Supply Chain Integration \&amp; Participation. Procedia Environ. Sci. 35, 140-149 (2016).

26. Hilty, L., Arnfalk, P., Erdmann, L., Goodman, J.: The relevance of information and communication technologies for environmental sustainability-a prospective simulation study. Model. Softw. (2006). 